\title{
KEBIJAKAN FISKAL UMAR BIN KHATTAB
}

\author{
Tina Arfah \\ Tinaarfah89@gmail.com \\ STEI Ar-Rachman Batam \\ Putri Jamilah \\ putrijamilah@umri.ac.id \\ Universitas Muhammadiyah Riau
}

\begin{abstract}
ABSTRAK
Tulisan ini membahas secara deskriptif kebijakan fiskal umar bin khatab. Khalifah Umar bin khatab merupakan khalifah kedua pasca masa Khulafaur Rasyidin. kebijakan fiskal adalah kebijakan yang dilakukan dalam mengelolah pendapatan dan pemasukan Negara. konsep kebijakan fiskal umar adalah konsep berdasarkan prinsiip syariah yang bertujuan untuk kemaslahatan umat. adapun kebijakan fiskal umar bin khattab adalah mendirikan lembaga baitul mal, mendirikan lembaga hisbah dan mendirikan lembaga-lembaga yang lain yang dapat menunjang perkonomian suatu Negara. Khalifah kedua ini sukses menerapkan kebijakan fiskal dalam menjalankan perekonomian dan bisa dijadikan acua dangan mengatur perekonomian Negara kita.
\end{abstract}

Kata kunci: baitul mal, kebijakan fiskal, kemaslahatan umat, umar bin khattab

\section{PENDAHULUAN}

Kehidupan manusia tidak bisa lepas dari kegiatan ekonomi. Ekonomi menjadi indicator kesejahteraan hidup masyarakat. Bagi pemerintahan Islam disebut dengan Ekonomi Islam yaitu Pemikiran ekonomi yang berlandaskan dari ajaran al-Quran, Sunnah, dan ijtihad serta pengalaman empiris. Sejarah pemikiran ekonomi Islam telah mencatat banyak namanama besar yang pemikirannya menjadi acuan praktik ekonomi Islam sampai hari ini. Salah satunya adalah tokoh muslim yang sangat tersohor yakni khalifah Umar bin Khatthab , beliau mampu menerapkan kebijakan fiscal sesuai dengan prinsip syariah sehingga pada masa itu kehidupan masyarakat sejahtera.

Umar bin Khatthab (581-644 M) bin Nafiel bin Abdul Uzza, lahir pada tahun $513 \mathrm{M}$ di Mekkah keturunan Bani Adiy, salah satu rumpun suku Quraisy, sekitar 12 tahun setelah kelahiran Rasulullah Saw. Kelahiran Umar bin Khatthab merupakan suatu peristiwa besar di kalangan suku Quraisy dikarenakan ayah Umar bin Khattab merupakan salah satu anggota terkemuka di tengah suku Quraisy. Ayahnya bernama Khattab dan ibunya bernama Hantamah binti Hasyim bin alMughirah al-Makhzumiyah. Hantamah merupakan sepupu dari AbuJahal yang juga suku Quraisy. Nasab Umar adalah Umar bin Khattab bin Nufail bin Abdul Uzza bin Riyah bin Abdullah bin Qarth bin Razah (al-Haritsi, 2010: 17). 
Umar bin Khatthab juga dikenal karena fisiknya yang kuat dimana perawakannya tinggi besar dan tegap dengan otot-otot yang menonjol dari kaki dan tangannya, jenggot yang lebat, berkumis tebal, rambut terurai dari kedua sisi kepalanya. Umar bin Khatthab juga menyemir rambutnya dengan Hana'(sejenis pacar) dan berwajah tampan, serta warna kulitnya coklat kemerahmerahan (al-Haritsi, 2010: 19). Umar bin khattab merupakan salah satu orang yang sangat membenci Islam sampai beliau berniat untuk membunuh nabi Muhammad S.A.W. HIdayah telah diberikan ALLAH SWT kepada umar melaui surah Tha-ha , beliau mendengarkan surah Tha-ha yang dibaca oleh Khabbab bin al-Arat dengan suara yang indah. Menyaksikan peristiwa tersebut, redamlah emosi dan hilanglah kemarahannya.

Umar menemui Nabi Muhammad untuk menyatakan masuk Islam pada tahun ke-6 dari masa kenabian (Haekal, 2002: 24). Semenjak Umar bin Khatthab memeluk agama Islam, kekuatan kaum Muslimin makin bertambah tangguh. Umar Bin al-Khatab adalah salah seorang dari tokoh-tokoh terbesar pada permulaan Islam dan pendiri imperium Arab. Adapun gelar bagi Umar Bin al- Khatab adalah al-Faruq, dikatakan bahwa dia digelari demikian karna terang terangannya dan pengumandangannya secara terbuka terhadap keIslamannya Dialah al-Faruq yang memisahkan antara yang hak dengan yang batil (Haekal, 2002: 64) dan penakluk terbesar yang pernah dihasilkan sejarah. Tidak hanya dalam penaklukan saja umar bin khattab terkenal dengan kebijakaan fiscal yang diterapkap pada masa itu sehingga masyarakat sejahtera.

\section{TEORI YANG RELEVAN}

Kebijakan fiskal adalah langkah-langkah pemerintah untuk membuat perubahanperubahan dalam sistem pajak atau dalam perbelanjaan dengan maksud untuk mengatasi masalah-masalah ekonomi yang dihadapi.7 Kebijakan fiskal meliputi langkahlangkah pemerintah membuat perubahan dalam bidang perpajakan dan pengeluaran pemerintah dengan maksud untuk mempengaruhi pengeluaran agregat (keseluruhan) dalam perekonomian (Sadono Sikorno, 2010).Menurut Rahardja dan Manurung (dikutip Chenny Seftarita, 2005), kebijakan fiskal adalah kebijakan yang dilakukan pemerintah untuk mengendalikan perekonomian dengan mengubah-ubah anggaran penerimaan dan pengeluran pemerintah.

Sedangkan Menurut Eko Suprayitno, kebijakan fiskal adalah kebijakan yang diambil pemerintah untuk membelanjakan pendapatannya dalam merealisasikan tujuan-tujuan ekonomi (Eko Suprayitno, 2005 ). Menurut M. Faried Wijaya (2000) dalam buku Nuruddin Mhd. Ali kebijakan fiskal adalah perubahan besarnya pajak dan atau pengeluaran pemerintah dengan tujuan menstabilkan harga serta tingkat output meupun kesempatan kerja dan memacu atau mendorong pertumbuhan ekonomi. Kebijakan fiskal menurut 
Mannan (1995) adalah, langkah pemerintah untuk membuat perubahan-perubahan dalam sistem perpajakan atau dalam pembelanjaan, yang bertujuan untuk mengatasi masalahmasalah ekonomi yang di hadapi Negara.

Dalam ekonomi konvensional kebijakan fiskal dapat diartikan sebagai langkah pemerintah untuk membuat perubahan-perubahan dalam sistem pajak atau dalam pembelanjaan (dalam konsep makro disebut dengan government expenditure) (Mustafa Edwin Nasution dkk.:2007).Dari beberapa definisi di atas dapat disimpulkan bahwa kebijakan fiskal merupakan suatu kebijakan pemerintah yang di dalamnya terdapat peraturan yang menyangkut penerimaan dan pengeluaran pemerintah dalam menjaga kegiatan ekonomi yang diinginkan atau kondisi yang lebih baik.

Kebijakan fiscal ini sudah ada sejak masa rasullulah, khalifhah dan sampai saat ini.Adapun kebijkn fiscal pada masa umar bin khattab adalah suatu kebijkan yang dilakukan khalifah mengenai pemasukan dan pengeluaran keuangan Negara.jadi tujuan kebijakan fiscal ini bagaimana cara mengatur keuangan Negara baik dari pemasukan maupun pengeluarankeuangan Negara. Adapun Tujuan dari kebijakan fiskal dalam Islam tidak terlepas dari prinsip-prinsip ekonomi Islam. Khurshid Ahmad (dikutipMuslimin H. Kara, 2005) mengkategorisasi prinsip-prinsip ekonomi Islam pada: Prinsip tauhid, rubbiyyah, khilafah, dan tazkiyah. Mahmud Muhammad Bablily menetapkan lima prinsip yang berkaitan dengan kegiatan ekonomi dalam Islam, yaitu: al-ukhuwwa (persaudaraan), alihsan (berbuat baik), al-nasihah (memberi nasihat), al-istiqamah (teguh pendirian), dan al-taqwa (bersikap takwa). M. Raihan Sharif dalam Islamic Social Framework, struktur sistem ekonomi Islam didasarkan pada empat kaidah struktural, yaitu: (1) trusteeship of man (perwalian manusia); (2) co-operation (kerja sama); (3) limite private property (pemilikan pribadi yang terbatas); dan (4) state enterprise (perusahaan Negara

\section{METODOLOGI}

Penelitian ini merupakan penelitian kualitatif dan menggunakan penelitian kepustakaan (Library Reseach). Penelitian kualitaif adalah prosedur penelitian yang menghasilkan data deskriptif berupa kata- kata tertulis atau lisan dari orang - orang dan perilaku yang dapat diamati Menurut (Moleong 2008). Metodologi penelitian ini disebut penelitian kualitatif karena mempertahankan orisinilitas data dalam bentuknya yang kualitatif .Sumber data dalam penelitian terdiri dari data primer dan data sekunder.Data primernya adalah Data diambil dari berbagai literatur berupa buku-buku yang berkaitan dengan objek penelitian, terutama yang berkaitan dengan ekonomi Islam dan kebijakan fiskal yang terjadi di masa khalifah Umar bin Al-Khathab. Sedangkan Data sekunder dalam penelitian ini digunakan untuk melengkapi dan mendukung informasi objek penelitian baik yang berbentuk buku, karya tulis, dan artikel yang berhubungan dengan objek penelitian. Metode pengumpulan data yang digunakan dalam penelitian ini adalah metode dokumentasi .Data yang diperoleh 
dalam penelitian ini lebih lanjut dianalisis dengan menggunakan metode kajian isi (content analisis) atau sering dikatakan sebagai analisis isi.

\section{STUDI PENELITIAN TERDAHULU}

Nurma Sari Dosen Program Studi Ekonomi Islam, Fakultas Ekonomi, Universitas Syiah Kuala Banda Aceh dengan judul Zakat Sebagai Kebijakan Fiskal Pada Masa Kekhalifah Umar Bin Khattab (jurnal perspektif ekonomi darussalam volume 1 nomor 2, September 2015 ISSN. 2502-6976) menjelaskan bahwa Zakat mempunyai kedudukan utama dalam kebijakan fiskal pada masa awal islam. Disamping sebagaisumber pendapatan Negara Islam yang utama pada masa itu, zakat juga mampu menunjang pengeluaranNegara baik dalam bentuk government expenditure (pengeluaran belanja negara) maupun government transfer(pengeluaran transfer). Zakat juga mampu mempengaruhi kebijakan ekonomi pemerintah islam untukmeningkatkan kesejahteraan rakyat terutama kaum lemah. Hal itu di karenakan zakat adalah sumber dana yang tidak akan pernah kering dan habis. Oleh karena itu, Untuk memanfaatkan dan mendayagunakan zakat dengan sebaik-baiknya, diperlukankebijaksanaan dari pemerintah atau pengelola zakat. Dana zakat tidak harus diberikan kepada yang berhaksecara apa adanya, tetapi dapat diberikan dalam bentuk lain yang dapat digunakan secara produktif yakni dapat dikelola lebih lanjut sehingga mendapat manfaat secara terus menerus.

Esti Alfiah IAIN IB Padang, dengan judul Pemikiran Ekonomi Umar Bin Khaththab Tentang Kebijakan Fiskal (Al-Intaj Vol. 3, No. 1, Maret 2017 Fakultas Ekoomi dan Bisnis Islam P-ISSN : 2476-8774/E-ISS : 2621-668X) menjelaskan bahwa Kebijakan Ekonomi Umar bin Khattab tentang kebijakan fiskal membuat kemajuan bagi umat Islam. Pendapatan negara terdiri dari berbagai zakat sebagai pajak, 1/5 hasil rampasan perang, jizyah, kharaj, dan 'ursyu. Pengelolaan dana dari berbagai sumber dana ini dikelola dengan baik, spesifik, dan tanggung jawab oleh beliau. Khalifah Umar tidak berjalan sendiri mengaturnya, ia mendirikan lembaga keuangan yaitu Baitul Mal denggan dilengkapi departement yang dibutuhkan sehingga perekonomian tetap stabil. Adapun perilaku Umar yang dapat diambil contoh untuk menjadi seorang pemimpin dalam hal ekonomi sebagai berikut : Bermusyawarah, Mengutamakan apa yang menjadi hak utama, yang utama adalah zakat orang yang berhak menerimanya, Menempatkan seseorang dalam bekerja sesuai dengan bidangnya dan Perekonomian dikatakan stabil apabila pemasukan sedikit dibandingkan pengeluaran.

Rizal Fahlefi lektor dalam mata kuliah ekonomi Mikro Islam STAIN Batusangkar dengan judul Kebijakan Ekonomi Umar Bin Khatthab menjelaskan bahwa Umar bin Khatthab secara rasional dan sadar telah mengukir prestasi besar dalam kepemimpinan nya. Kebijakan politik ekonomi Umar bin Khattab dengan ketegasan dan pengawasan yang ketat, terbukti menjadi landasan bagi kemajuan kepemimpinan Umar di berbagai sektor 
ekonomi. Dengan keberhasilan yang telah diraihnya tersebut, Umar bin Khattab ditempatkan menjadi salah seorang tokoh pemimpin dari 100 tokoh paling berpengaruh di dunia. Konsep mashlahah Jami'iyyah merupakan dasar dan landasan pokok bagi Umar bin Khatthab dalam menjalankan roda perekonomian umat sebagai bentuk pengejewantahan dari perintah agama, karena dalam urusan muamalah (ekonomi) yang menjadi pertimbangan utama adalah asas mashlahah dan manfaat bagi masyarakat. Inilah konsep rahmatan lil 'alamin yaitu membawa rahmat bagi semesta alam.

Muhammad Fauzan Dosen STIKOM Tunas Bangsa Pematangsiantar Sumatera Utara dengan judul Kebijakan Fiskal Dalam Perekonomian Islam Di Masa Khalifah Umar Bin AlKhathab (human falah: Volume 4. No. 1 Januari - Juni 2017 menjelaskan bahwa Pada dasarnya kebijakan fiskal yang terjadi di masa khalifah Umar bin AlKhathab berbeda dengan kebijakan fiskal di Indonesia. Hal ini terjadi karena kebijakan fiskal di masa khalifah Umar bin Al-Khathab berdasarkan Islam yaitu Al Qur"an, Hadis dan ijma" para sahabat di masa itu, sedangkan kebijakan fiskal di Indonesia tidak berdasarkan Islam. Adapun yang menjadi sumber-sumber devisa (pendapatan) negara Islam pada masa Umar bin Al-Khathab adalah zakat, usyur, ghanimah (khums), sedekah, kharaj, fa"i, jizyah, dan pendapatan lainlainnya. Sedangkan belanja (pengeluaran) negara terdiri dari pendistribusian zakat dan usyur kepada delapan ashnaf, pendistribusian ghanimah (khums) dan sedekah kepada fakir miskin untuk membiayai kesejahteraan mereka tanpa membedakan apakah ia seorang Muslim atau bukan, pendistribusian fa"i, kharaj, jizyah, usyur, dan sewa tanah untuk membayar dana pensiun dan dana bantuan serta untuk membiayai operasional administrasi dan militer, dan yang terakhir pendistribusian pendapatan lain-lain untuk membayar para pekerja, anak-anak terlantar, dan dana sosial lainnya. Adapun sumber-sumber devisa (pemasukan) negara Indonesia terdiri dari penerimaan pajak (pajak dalam negeri dan pajak perdagangan internasional) dan penerimaan negara bukan pajak yang terdiri dari penerimaan SDA, bagian laba BUMN, PNBP lainnya dan pendapatan BLU. Sedangkan belanja negara Indonesia pada saat ini terdiri dari belanja pegawai, belanja barang, belanja modal, pembayaran bunga utang, subsidi, belanja hibah, bantuan sosial, dan belanja lain-lain.

Dody Hermanto,Drs. Kamaruddin Oemar. M.Si dan Asril. M.Pd dengan judul Pelaksanaan Kebijakan Ekonomi Pada Masa Kekhalifahan Umar Bin Khattab (634 - 644 M) menjelaskkan bahwa Diantara kebijakan Umar bin Khattab adalah kebijakan selama masa krisis tahun Ramadah, kebijakan dalam krisis moneter, kebijakan dalam independensi baitul mal dan pembukuan administrasi keuangan Negara yang di dalamnya termasuk perihal zakah, kharaj, jizyah dan usyur, kebijakan dalam pengelolaan sumber daya bumi dan hisbah dalam pengawasan pasar. Kebijakan yang diberlakukan semasa kekhalifahan Umar memiliki pengaruh, baik pada masa pemerintahannya, pada masa setelahnya maupun sampai pada masa sekarang. Ini menunjukkan kebijakan yang dilaksanakan pada 
masa pemerintahan Umar relevan dengan perkembangan zaman. Kebijakan Umar juga memiliki nilai-nilai pendidikan, diantara adalah sikap tolong menolong, rasa tanggung jawab, kejujuran, musyawarah untuk mufakat, sikap tegas dalam memimpin dan menjamin keadilan dengan menghindari dari kecurangan.

Khomsyahrial Romli (UIN Raden Intan Lampung) Nelly Marhayati (IAIN Bengkulu) dkk dengan judul Manajemen Baitul Mal Pada Masa Khalifah Umar Bin Khathab R.A: Sebuah Tinjauan Sejarah (jurnal ilmiah syiar Jurusan Dakwah, FUAD, IAIN Bengkulu Vol. 19, No. 01, Januari Juni 2019) menjelaskan bahwa Umar bin Khathab menjadi khalifah sekitar 10 tahun. Dia sangat dikenal sebagai kebijakan ekspansinya. Dia memperkenalkan sistem administrasi pemerintahan dengan membagi wilayahnya dan membangun Baitul mal menjadi lembaga independen. Kebijakankebijakan perluasan itu telah mencapai tujuan dengan sukses, sehingga pendapatan orang-orang Baitul mal itu terlalu banyak. Kemudian, khalifah Umar mengaturnya melalui akumulasi dan emisi dengan membentuk Diwan. Dia telah menerapkan konsep manajemen Islam jauh sebelum manajemen weit exisheted. Konsentrasi Umar memberikan preferensi pada cara yang terkait dengan nilai iman dan kebenaran. Dia juga menerapkan konsep Syura pada cara dan aktivitas manajemen, terutama yang terkait dengan penentuan keputusan. Membagi daerah pemerintahan dan Amir dan Madinah sebagai pusat pemerintahan dan Baitu mal sebagai lembaga independen yang keluar dari campur tangan pemerintah menjadi kontribusi Umar.

\section{HASIL DAN PEMBAHASAN}

Kebijakan Ekonomi Umar bin Khattab tentang kebijakan fiskal membuat kemajuan bagi umat Islam.kebijakan fiscal umar bin khattab yaitu bagaimana umar mengelolah pemasukan dan pengeluaran keuangan Negara adapun pendapatan umat muslim pada saati itu terdiri dari:zakat,usyur,Fa'I Jizyah dan pendapatan yang lain.

\section{Zakat}

Menurut bahasa zakat artinya tumbuh dan berkembang, atau menyucikan karena zakat akan mengembangkan pahala pelakunya dan membersihkannya dari dosa. Menurut syariat, zakat ialah hak wajib dari harta tertentu pada waktu tertentu(Fahrur Mu'is:22). Menurut Sayyid Sabiq ( dikutip Asnaini, 2008) zakat adalah suatu sebutan dari suatu hak Allah yang dikeluarkan seseorang untuk fakir miskin. Dinamakan zakat, karena dengan mengeluarkan zakat di dalamnya terkandung harapan untuk memperoleh berkah, pembersihan jiwa dari sifat kikir bagi orang kaya atau menghilangkan rasa iri hati orangorang miskin dan memupuknya dengan berbagai kebajikan .Ajaran islam menjadikan zakat sebagai ibadah maliah ijtima'iyah yang mempunyai sasaran sosial untuk membangun satu sistem ekonomi yang mempunyai tujuan kesejahteraan dunia dan akhirat. Tujuan di syari'atkan zakat adaah sebagi berikut: 
a. Mengangkat derajat fakir miskin dan membantunya keluar dari kesulitan hidup dan penderitaan.

b. Membantu memecahkan masalah yang dihadapi oleh orang yang berutang, ibnu sabil, dan mustahiq lainnya.

c. Membina tali persaudaraan sesama umat Islam.

d. Menghilangkan sifat kikir dari pemilik harta

Pada masa umar bin khattab ini pendistribusian zakat dilakukan dengan baik dan tepat sasaraan sehingga masyarakat sejahtera sesuai dengan maqhasid syariah.Hal ini terbukti dengan contoh sebagai berikut: Abu Ubaid menuturkan bahwa Muadz pada masa Umar bin al-Khattab pernah mengirimkan hasil zakat yang dipungutnya di Yaman kepada Umar di Madinah karena tidak dijumpai lagi orang yang berhak menerima zakat di Yaman. Namun Umar bin al-Khattab mengem-balikannya. Kemudian Muadz mengirimkan sepertiga hasil zakat itu, Umar kembali menolaknya dan berkata, "Saya tidak mengutus-mu sebagai kolektor upeti, tetapi saya mengutusmu untuk memungut zakat dari orang-orang kaya di sana dan membagikannya kepada kaum miskin dari kalangan mereka juga." Muadz menjawab,"Kalau saya menjumpai orang miskin di sana, tentu saya tidak akan mengirimkan apa pun kepadamu." Pada tahun kedua, Muadz mengirimkan separuh hasil zakat yang dipungutnya kepada Umar, tetapi Umar mengembalikannya. Pada tahun ketiga, Muadz mengirimkan semua hasil zakat yang dipungutnya, yang juga dikembalikan Umar. Muadz berkata, "Saya tidak menjumpai seorang pun yang berhak menerima bagian zakat yang saya pungut (Abu Ubaid, 2009).

\section{Kharaj}

Dalam bahasa Arab kharaj berasal dari kata akhraja-yakhrujuikhrajan, jamaknya alikhraj yang artinya dikeluarkan. Dalam kitab alAhkam al-Sulthaniyah Abi Hasan alMawardi menjelaskan bahwa kharaj adalah sesuatu yang dimiliki oleh hamba tanah dan terdapat hak untuk diambilnya (Oemar Bakry dan Abd. Bin Nuh, 1983). Kharaj sebagai sistem pemungutan pajak yang dikenakan atas hasil pertanian pernah efektif diterapkan pada masa pemerintahan Umar r.a. Umar telah menata sistem perpajakan atas tanah pertanian yang dikenakan pada non muslim.Pada masa itu, kehidupan ekonomi, sosial dan politik semakin komplek(Irfan Mahmud Ra'ana,1992).

Menurut (Irfan Mahmud Ra'ana, 1992) Dalam sistem pelaksanaannya Umar menetapkan kharaj berdasarkan beberapa aspek. Misalnya, kharaj hanya dipungut pada kafir dzimi, luas tanah, hasil produksi atas tanah yang digarap oleh kafir dzimi. Sehingga dalam pelaksanaannya kharaj tidak memberatkan bagi mereka (dzimi). Umar menyatakan dalam pidato politiknya, sebagaimana dijelaskan oleh Abu Yusuf dalam bukunya, al-Kharaj; 
"wahai manusia, sesungguhnya tidak ada suatu hak bagi siapapun untuk ditaati dalam perbuatan maksiat dan saya tidak mendapatkan suatu harta yang maslahat kecuali dalam tiga cara, yaitu; diambil dengan haknya dan diberikan kepada yang berhak dan dilarangnya atas kebatilan ( Abu Yusuf Ya'qub bin Ibrahim:117) Kemudian Umar menandaskan, bahwasannya ia tidak akan pernah memungut suatu pajak atas hasil yang kamu peroleh dari Allah kecuali dengan jalan yang sebenarnya dan kamu sekalian tidak berhak mengeluarkan sesuatu yang telah berada di tanganku kecuali dengan haknya (Abu al-'Ala al-, 1984).

\section{Usyur}

Usyur bukan berasal dari Alquran maupun sunnah akan tetapi merupakan ijtihaj para sahabat dan hanya berlaku bagi kaum Yahudi dan Nasrani sebesar 1/10 dari setiap barang dagangan yang dibawa untuk diperdagangkan dan harganya telah melebihi 200 dirham (Quthb, 2002).Usyur merupakan hak kaum muslim yang diambil dari harta serta perdagangan ahlu dzimmah dan penduduk Harbi yang melewati perbatasan negara khalifah. Secara etimoligi usyur berarti sepersepuluh. Secara terminologi usyur berarti pajak yang dikenakan terhadap barang dagangan yang masuk ke negara Islam. Usyur diistilahkan oleh pajak perdagangan ataupun disebut bea-cukai pada masa sekarang. Pajak perdagangan ini mulai di kenal sejak masa khalifah Umar bin Khattab. Latar belakang penerapan usyur ini terjadi karena pada masa Umar berdasarkan laporan Musa al-Asyari bahwa para pedagang muslim yang berdagang ke wilayah non-muslim dipungut pajak perdagangan oleh pemerintah wilayah setempat.

Penduduk yang pertama kali di pungut usyur adalah kafir Harbi. Dalam menerapkan usyur, khalifah menunujuk petugas yang berwenang untuk memungut usyur dengan mendirikan lembaga Thaifah al-Usyur. Lembaga ini bertugas memungut usyur dan memberi sertifikat kepada mereka yang telah melunasi usyur ataupun memberi sanksi kepada mereka yang enggan membayar. Pemungutan tersebut dilakukan oleh Ziyad bin Hudair seperti diceritakan oleh Abu Ubaid al-Qasim dalam kitab al-amwal sebagai berikut: Dari Ziyad ziyan bin hudair ia berkata saya telah dilantik umar menjadi petugas cukai. Lalu dia memerintahkan supaya mengambil cukai barang impor dari para pedagang kafir harbi sebanyak usyur, barang impor pedagang ahli dzimah sebanyak seperlima, dan barang impor pedagang kaum muslimin sebanyak seperempat dari usyur (Abu Ubaid al-Qasim, 2006).

Dalam pemungutan usyur ini, Umar bin Khatab selalu mempertimbangkan dua hal, yaitu barang-barang yang dikenakan usyur hanya barang perdagangan dan nilainya 200 dirham (Nurul Huda dkk, , 2012). Usyur dipungut atas seluruh jenis barang dagangan, misalnya perhiasan, hewan, hasil pertanian dan buah-buahan dan apabila perdagangan mereka melewati perbatasan negara serta dipingut setahun sekali. Kadar usyur yang 
dipungut 20 dinar untuk emas dan 200 dirham untuk perak).Kadar usyur tingkat perdagangan berkisar dari 2,5 pertahun untuk pedagang muslim, 5\% untuk ahlu zimmah dan 10\% untuk untuk para pedagang kafir harbi. Kadar usyur yang dipungut mencapai 20 dinar (Qadhi Abu Yusuf Ya'qub ibn Ibrahim ,1989).Dalam memperlakukan ketentuan usyur Umar menerapkan prinsip keadilan. Besarnya pungutan usyur pada kafir dzimmi dan kafir Harbi merupakan wewenang khalifah dengan perlakukan seimbang.

4. Jizyah

Jizyah dalam ilmu fiqh berarti pajak kepala atau pajak perseorangan yang dikeluarkan terhadap orang-orang non-muslim (ahl alz|immah) tertentu yang telah mengikat perjanjian dengan pemerintah.Dengan kata lain, jizyah merupakan pajak per kepala yang dipungut oleh pemerintah islam dari orang laki-laki non-islam, merdeka, balig, berakal, sehat, dan kuat, sebagai imbangan bagi keamanan diri mereka ( Abdul Fatah, 526). Ketentuan mengenai jizyah berdasarkan al-Qur"an, sunnah dan ijma". Seperti ditegaskan dalam kandungan makna ayat al-Qur-an surat at At-Taubah ayat 29. 4 Ayat ini turun pada tahun ke sembilan Hijriyah ketika Islam telah tersebar dan menguat dengan dikuasainya kota Makkah oleh kaum muslimin serta hadirnya sekian banyak delegasi suku-suku Arab mengakui kerasulan Nabi Muhammad Saw. Ayat ini adalah ayat pertama turun berkenaan perintah memerangi ahl al-kitab, setelah pada ayat sebelumnya Allah Swt. membicarakan tentang pelarangan memasuki Masjidil Haram bagi kaum musyrik dan memutuskan hubungan perdagangan dengan mereka. Kekhawatiran muncul di kalangan kaum muslimin dimana situasi itu akan berakibat buruk bagi perekonomian mereka, maka ayat ini turun untuk menghilangkan kecemasan karena sebagai gantinya kaum muslim dapat memungut jizyah dari ahl al-kitab (al-Suyuti, t.th, 410).

Khalifah Umar juga mengambil jizyah dari selain orang ahli kitab seperti Majusi Persia seperti Rasulullah mengambil jizyah dari orang Majusi Hijir. Seperti yang telah di jelaskan oleh Abu Ubaid al-Qasim; Dari Syihab bahwa Rasulullah mengambil jizyah dari orang-orang Majusi Hajr, Umar juga telah mengambil jizyah dari orang Majusi Persia dan Utsman telah mengambil jizyah dari Majusi Barbar (Abu Ubaid al-Qasim, 2006). Menurut Mahmud Irfan Raana, Khalifah Umar tidak membebankan jizyah kepada kaum wanita, anak-anak, orang-orang miskin, para budak dan rahib-rahib. Pemerintahan khalifah Umar sangat berlaku lemah lembut terhadap orang-orang miskin dan lemah, namun bersikap keras terhadap orang-orang kaya agar mereka tidak menghindar dari kewajiban membayar jizyah. Jizyah juga tidak diwajibkan atau dibebaskan atas orang yang memeluk Islam. Tapi jizyah tidak gugur karena kematian. Jika seseorang mati pada saat jatuh tempo membayar jizyah setelah setahun, maka ia tetap wajib membayar jizyah, karena dianggap hutang. Membayarnya menggunakan harta peninggalan. 
Pada masa Nabi saw. jizyah dipungut secara sederhana, dengan menunjuk seorang administrator yang jujur di setiap kota dan dibantu oleh seorang asisten yang memfasilitasi persoalan "teknis" dengan perwakilan dari kaum dhimmi. Berbeda halnya pada masa kepemimpinan Umar ibn Khatab, prosedur pemungutan jizyah diserahkan kepada unit-unit bayt al-mal di provinsi. Umar memberikan otoritas penuh kepada gubernur dalam operasional jizyah serta bertanggung jawab kepada pusat terhadap sejumlah pengeluaran dan pendapatan negara melalui jizyah. Khalifah Umar tidak menyalurkan semua dana yang ada, akan tetapi sebagian dana tersebut dijadikan sebagai cadangan kas negara untuk menutupi kekurangan-kekurangan .

\section{5. .Fa'i}

Fa'iadalah harta rampasan yang diperoleh dari musuh tanpa terjadinya pertempuran.Selain zakat, kharaj, usyur dan Jizyah, Fa;I atau Harta rampasan perang merupakan sumber pendapatan negara yang fungsinya tidak kalah penting dengan sumber-sumber pendapatan lainnya. Harta fa'I digunakan untuk kepentingan umat dan kesejahteraan masyarakat.

Dalam mengatur pemasukan dan pengeluaran keuangan negara ummar bin khattab mendirikan baitul mal. Baitul Mal berasal dari bahasa Arab yaitu dari kata bait yang berarti rumah dan al-mal berarti harta.baitul mal berarti rumah untuk mengumpulkan dan meyimpan harta. Baitul Mal adalah suatau lembaga atau pihak (al jihat) yang mempunyai tugas khusus menangani segala harta umat, baik berupa pendapatan maupun pengeluaran negara. Baitul mal dapat diartikan juga secara fisik sebagai tempat (al-makan) untuk menyimpan dan mengelola segala macam harta yang menjadi pendapatan negara. Dalam baitul mal terdapat harta negara yang berasal dari pendapatan negara baik dari, zakat, kharaj,usyur, ghanimah, fa'I ,jizyah dan pendapatan lainnya semua pendapatan ini tercatat dalam pembukuan administrasi negara, termasuk perihal pendistribusiannya, mengenai siapa penerimanya dan untuk apa tujuan penggunaannya. untuk keperluan pendataan penduduk yang mendapatkan tunjangan dari bayt al-mal, khalifah menunjuk komite untuk membuat laporan sensus penduduk sesuai tingkat kepentingan dan kelasnya (Amalia, 2005). Sehingga manajemen baitul mal terstruktur degan efektif dan efisien.

Table 01: pendistribusian pendapatan Negara pada masa umar bin khattab

\begin{tabular}{|l|l|}
\hline Pendapatan Negara & Tujuan penggunaan \\
\hline Zakat dan Usyur & $\begin{array}{l}\text { Pendapatan ini didistribusikan di tingkat } \\
\text { lokal dan jika terdapat surplus, sisa } \\
\text { pendapatan tersebut disimpan di Baitul Mal } \\
\text { pusat dan dibagikan kepada delapan ashnaf }\end{array}$ \\
\hline Ghanimah (khums) dan Sedekah & $\begin{array}{l}\text { Pendapatan ini didistribusikan kepada fakir } \\
\text { miskin atau untuk membiayai kesejahteraan }\end{array}$ \\
\hline
\end{tabular}




\begin{tabular}{|l|l|}
\hline & $\begin{array}{l}\text { mereka tanpa membedakan apakah ia } \\
\text { seorang Muslim atau bukan }\end{array}$ \\
\hline Kharaj, Fa"i, Jizyah, Usyur dan Sewa Tanah & $\begin{array}{l}\text { Pendapatan ini digunakan untuk membayar } \\
\text { dana pensiun dan dana bantuan serta untuk } \\
\text { membiayai biaya operasional administrasi, } \\
\text { kebutuhan militer, dan sebagainya }\end{array}$ \\
\hline Pendapatan lain-lain. & $\begin{array}{l}\text { Pendapatan ini digunakan untuk membayar } \\
\text { para pekerja, pemeliharaan anak-anak } \\
\text { terlantar, dan dana sosial lainnya. }\end{array}$ \\
\hline
\end{tabular}

Sumber: (Adiwarman Karim: 2008, 74)

Adapun ketentuan dalam pendistribusian harta di Batul Mal, sebagai berikut ( Muhammad Hidayat, 2010:186-187):

a. Para pejabat Baitul Mal tidak mempunyai wewenang dalam membuat suatu keputusan terhadap harta di Baitul Mal yang berupa zakat dan 'usyur.

b. Harta Baitul Mal dianggap sebagai harta kaum muslimin, sedangkan khalifah dan para amil hanya berperan sebagai pemegang amanah.

c. Ditingkat Provinsi, pejabat yang bertanggung jawab terhadap harta umat tidak bergantung pada Gubernur dan mereka mempunyai otoritas penuh dalam melaksanakan tugasnya serta bertanggung jawab langsung kepada pemerintahan pusat. Dengan kata lain pihak eksekutif tidak boleh turut campur dalam mengelola harta baitul mal

Bersamaan dengan reorganisasi lembaga baitul mal, sekaligus sebagai perealisasian salah satu fungsi negara Islam, yakni fungsi jaminan sosial, Khalifah Umar membentuk sistem diwan yang menurut pendapat yang terkuat mualai dipraktekkan untuk pertama kali pada tahun $20 \mathrm{H}$. Dalam rangka ini, khalifah menunjuk sebuah komite nassa ternama yang tyerdiri dari Aqil bin Abi Thalib, Mahzamah bin Naufal dan Jabir bin Mut'im untuk membuat laporan sesnus penduduk sesuai dengan tingkat kepentingan dan golongannya (Irfan Mahmud Ra'ana,1992:155).Daftar tersebut tersebut disusun secara berurutan dimulai dari orang-orang yang mempunyai hubungan kekerabatan dengan Nabi Muhammad SAW, para shabat yang ikut perang badar dan uhud, para imigran ke Abysinia dan madinah, para pejuang Qodisiyah atau orang-orang yang menghadiri perjanjian Hudaibiyah dan seterusnya.

Selain membangun baitul mal, Membangun lembaga al-Hisbah juga merupakan salah satu kebijakan yang dilakukan oleh umar bin khattab yang mana lebaga inibertugas untuk mengawasi pasar supaya tidak terjadi monopoli dan oligopoly pasar. Pada masa Rasululloh S.AW pengawasan pasar sudah pernah diterapkan, Rosullulloh S.AW mengangkat 
beberapa orang sahabat yang diberi tugas untuk mengawasi jalannya suatu transaksi bisnis. Khalifah umar bin khattab menghidupkan kembali pengawasan pasar (al-Hisbah), yang mana al-hisbah menjadi suatu lembaga khusus yang mengawasi hal- hal yang terjadi dalam pasar. Umar sangat sering turun langsung ke pasar untuk mengontrol harga-harga yang berlaku, tujuan Umar bin Khatthab adalah agar tidak terjadi kecurangan. suatu riwayat dikatakan bahwa Umar pernah memarahi Habib bin Balta'ah menjual kismis dengan sangat murah. Untuk menjaga kestabilan harga pasar dan orang lain dapat pula menjual kismis yang sama, maka Umar memerintahkan agar Habib menaikkan harga sesuai harga pasar (al-Haritsi, 2006).

\section{Relevansi Antara Kebijakan Fiskal di Masa Umar bin Al-Khathab dengan Kebijakan Fiskal dalam Indonesia}

Secara umum, kebijakan fiskal di masa khalifah Umar bin Al-Khathab mempunyai banyak perbedaan dengan kebijakan fiskal di Indonesia. Hal ini terjadi karena di masa Umar bin Al-Khathab sistem ekonomi yang digunakan bersumber dari Al-Qur"an dan Hadis sedangkan ekonomi di Indonesia pada saat ini menggunakan sistem ekonomi campuran yaitu perpaduan antara ekonomi kapitalisme dengan ekonomi sosialisme yang bersumber dari pemikiran manusia pada masa khalifah Umar bin khatab sumber pendapatan terdiri dari zakat, kharaj,usyr, Fa'I ,Jizyah dll. Sedangkan di Indonesia sumber pendapatan terdiri dariPajak, Retribusi, Keuntungan dari perusahaan-perusahaan Negara, Denda-denda dan penyitaan yang dilakukan oleh Negara, Sumbangan masyarakat untuk jasa-jasa yang diberikan oleh pemerintah, Pencetakan uang kertas, Hasil undian Negara, Pinjaman, Hadiah atau hibah. Sedangkan pengeluaran yang dilakukan pemerintah dapat dibedakan menjadi dua macam: Pengeluaran konsumsi pemerintah yang bisa juga disebut government expenditure atau government purchase.; Pengeluaran pemerintah berupa government transfer (M. Fauzan,2017).

Dalam hal belanja negara juga mempunyai beberapa perbedaan antara sistem belanja negara pada masa Umar bin Al-Khathab dengan sistem belanja negara Indonesia pada saat ini. Pada masa Umar bin Al-Khathab belanja negara (distribusi pendapatan negara) terdiri dari pendistribusian kepada delapan ashnaf jika pendapatannya terdapat surplus pendapatan, pendistribusian kepada para fakir miskin atau untuk membiayai kesejahteraan mereka tanpa membedakan apakah ia seorang muslim atau tidak, pendistribusian untuk membayar dana pensiun dan dana bantuan serta untuk menutup biaya operasional administrasi, kebutuhan militer, dan sebagainya serta pendistribusian untuk membayar para pekerja, pemeliharaan anak-anak terlantar, dan dan dana sosial lainnya.Sedangkan sistem belanja negara Indonesia pada saat ini terdiri dari belanja pegawai, belanja barang, belanja modal, pembayaran bunga utang, subsidi, belanja hibah, bantuan sosial, dan belanja lain-lain. 
Untuk mengatur perekonomian kita saat ini ,kebijakan fiscal umar bin kattab dapat kita jikan acuan atau refrensi dalam mengatur perekonomian Negara. Kebijakan fiscal umar bin khattab terbukti dapt menjaadikan ekonomi stabil dan masyarakat, sebab dalam hal pemasukan dan pengeluaran keuangan Negara hanya dimaanfaatkan untuk kemaslahatan umat tanpa mementingkan keuntungan pribadi.walaupun sumber pendapatan pada masa umar berbeda dengan sumber pendapatan di Indonesia. Pajak merupakan sumber pendapatan terbesar di Indonesia ,jika ini dikelolah dengan efektif, efisien ,transparan , akuntabel dan paling penting dikelolah untuk kepentingan umat maka akan tercipta masyarakat yang sejahtera sesuai dengan Maqhasid syariah.Selain pajak, zakat juga merupakan sumber pendapatan Negara terbesar disebabkan Negara kita merupakan penduduk mayoritas muslim terbesar jika ini dikelolah sesuai prinsip syariah maka perekonomia Indonesia akan maju dan stabil.

\section{KESIMPULAN}

Umar bin Khatthab sebagai khalifah kedua sukses dalam mengatur pemerintahan dan ekonomi negara. Sehingga tidak salah jika dikatakan bahwa Umar bin Khatthab telah menunjukkan kepada dunia bahwa ekonomi yang berdasarkan prinsip syariah tidak menghalangi daya kreatif dan inovasi seorang pemimpin tertinggi sebuah negara dalam mewujudkan negara yang damai dan makmur.kebijakan fiscal yang diterapkan umar bin khattab yang mampu meningkatkan kesejahteraan umat antara lain mendirikan baitul mal yang berfungsi untuk mengelola pemasukan dan pengeluaran keuangan Negara, mendirikan lembaga al hisbah yang berfungsi untuk melakukan pengawasan di pasar, dan mendirikan lembaga -lembaga lain yang dapat menunjang perekkonomian yang stabil sehingga umat sejahtera.

Untuk mengatur perekonomian kita saat ini ,kebijakan fiscal umar bin kattab dapat kita jikan acuan atau refrensi dalam mengatur perekonomian Negara. Kebijakan fiscal umar bin khattab terbukti dapt menjaadikan ekonomi stabil dan masyarakat, sebab dalam hal pemasukan dan pengeluaran keuangan Negara hanya dimaanfaatkan untuk kemaslahatan umat tanpa mementingkan keuntungan pribadi.walaupun sumber pendapatan pada masa umar berbeda dengan sumber pendapatan di Indonesia. Pajak merupakan sumber pendapatan terbesar di Indonesia ,jika ini dikelolah dengan efektif, efisien ,transparan , akuntabel dan paling penting dikelolah untuk kepentingan umat maka akan tercipta masyarakat yang sejahtera sesuai dengan Maqhasid syariah.Selain pajak, zakat juga merupakan sumber pendapatan Negara terbesar disebabkan Negara kita merupakan penduduk mayoritas muslim terbesar jika ini dikelolah sesuai prinsip syariah maka perekonomia Indonesia akan maju dan stabil. Jadi kebijakan fiscal umar bin khattab dapat kita jadikan acuan Dallam kebijakan fiscal di Indonesia. 


\section{SARAN}

Dari kesimpulan yang diperoleh dari hasil penelitian maka penulis mengharapkan beberapa hal sebagai berikut: Bagi dunia akademisi, disarankan dapat lebih memperluas penelitian bukan hanya pada masa Khulafaur Rasyidin akan tetapi juga pada zaman-zaman keemasan Islam yang telah berlalu. Penelitian ini baru menjangkau kajian konsep ekonomi Islam berdasarkan data konseptual dari para pemikir ekonom muslim. Sehingga perlu kajian lanjutan konsep ekonomi Islam berdasarkan pedoman praktisnya dalam lapangan empiris.

\section{DAFTAR PUSTAKA}

Abu al-'Ala al-Maududi, Khilafah wa al-Mulk. (1984) terj. M. Baqir "Khilafah dan Kerajaan", Bandung: Mizan.

Abu Ubaid al-Qasim. (2006) .Kitab Al-Amwal, terjemahan Setiawan Budi Utomo, Jakarta:Gema Insani.

Abu Yusuf Ya'qub bin Ibrahim, Kitab al-Kharaj. (2008). Kairo: al-Matba'ah al-Salafiyah.

Asnaini. (2008) .Zakat Produktif dalam Perspektif Hukum Islam, Yogyakarta: Pustaka Pelajar, 2008.

Chenny Seftarita. (2005) .Kebijakan Fiskal, Kebijakan Moneter, dan Pertumbuhan Ekonomi Di Indonesia, Simposium Riset Ekonomi Ii Surabaya,

Eko Suprayitno (2005) Ekonomi Islam Pendekatan Ekonomi Makro Islam dan Konvensional, Yogyakarta: Graha Ilmu

Fahrur Mu'is, Zakat A-Z Panduan Mudah, Lengkap, dan Praktis tentang Zakat, Solo: Tinta Medina, cet. 1

Irfan Mahmud Ra'ana (1992) Sistem Ekonomi Pemerintahan Umar Ibn Khattab, Yogyakarta: Pustaka Firdaus.

Muhammad Hidayat (2010) An Introduction The Sharia Economic (Pengantar Ekonomi Syariah), Jakarta : Zikrul Hakim

Muslimin H. Kara (2005) Bank Syariah di Indonesia Analisis Terhadap Pemerintah Indonesia Terhadap Perbankan Syariah, Yogyakarta: UII Press,

Nurul Huda dkk (2012) Keuanagan Publik Islam Pendekatan Teoritis dan Sejarah, Jakarta: Kencana Prenada Gurp.

Oemar Bakry dan Abd. Bin Nuh (1983) Kamus Indonesia-Arab-Inggris, Jakarta: Mutiara.

Sadono Sikorno (2010) Pengantar Teori Makro Ekonomi, Jakarta: Raja Grafindo Persada. 